\title{
Secondary Health Care: best practices in the health services network
}

\author{
Alacoque Lorenzini Erdmann ${ }^{1}$ \\ Selma Regina de Andrade ${ }^{2}$ \\ Ana Lúcia Schaefer Ferreira de Mello² \\ Livia Crespo Drago ${ }^{3}$
}

Objective: to understand the organization of health practices, based on the interactions at the secondary care level, and to analyze how the actions and services at this level of care contribute to the development of best practice in health. Method: a qualitative approach, based in Grounded Theory. Data was obtained from individual interviews, with managers, health care professionals and health service users making up the sample group representing the secondary level of healthcare. The theoretical model was formulated based on four categories, analyzed based in the elements of the network modeling of health care theoretical framework. Results: The organization of health practices at a secondary level is in the process of consolidation and is contributing to the development of best practices in the locale studied. Conclusion: The broadening of access to consultations and specialized procedures, and the articulation of the network's points, are aspects of this level of care which are considered essential for care which is effective and integral. This study contributes to the analysis of health practices from the perspective of network modeling, based on the interactions between secondary care and the health system's other health facilities, which are shown as going through a process of consolidation in the locale studied.

Descriptors: Public Health Practice; Unified Health System; Health Systems; Delivery of Health Care.

\footnotetext{
1 PhD, Full Professor, Universidade Federal de Santa Catarina, Brazil.

2 PhD, Professor, Universidade Federal de Santa Catarina, Brazil.

${ }^{3}$ Master's student, Universidade Federal de Santa Catarina, Brazil. Scholarship holder from Bolsista da Coordenação de Aperfeiçoamento de Pessoal de Nível Superior (CAPES).
} 


\section{A atenção secundária em saúde: melhores práticas na rede de serviços}

Objetivo: compreender a organização das práticas de saúde, a partir das interações no nível da atenção secundária, e analisar como as ações e serviços nesse nível de atenção têm contribuido para o desenvolvimento de melhores práticas em saúde. Método: trata-se de abordagem qualitativa, apoiada no método da Teoria Fundamentada nos Dados. Os dados obtidos em entrevistas individuais, com gestores, profissionais de saúde e usuários, compôs o grupo amostral, representativo do nível de atenção secundária. Formulou-se o modelo teórico a partir de quatro categorias, analisadas com base nos elementos da modelagem de rede de atenção à saúde. Resultados: a organização das práticas de saúde, no nível secundário, está em processo de consolidação e vem contribuindo para o desenvolvimento de melhores práticas em saúde no local estudado. Conclusão: a ampliação do acesso a consultas e procedimentos especializados e articulação dos pontos da rede são aspectos desse nível de atenção, considerados imprescindíveis para a resolubilidade e integralidade do cuidado. Este estudo contribui para a análise das práticas em saúde na perspectiva da modelagem de redes, a partir das interações da atenção secundária e dos demais pontos do sistema de saúde, que se mostram em processo de consolidação no local estudado.

Descritores: Prática de Saúde Pública; Sistema Único de Saúde; Sistemas de Saúde; Rede de Cuidados Continuados de Saúde.

\section{La atención secundaria en salud: mejores prácticas en la red de servicios}

Objetivo: Comprender la organización de las prácticas de salud, desde las interacciones en el nivel de la atención secundaria y analizar cómo las acciones y servicios en este nivel han contribuido al desarrollo de mejores prácticas en salud. Método: Enfoque cualitativo, apoyado en la Teoría Fundamentada en los Datos. Se realizaron entrevistas con gestores, profesionales de salud y usuarios, que conforman el grupo muestral de la atención secundaria. Resultados: Se formuló el modelo desde cuatro categorías, analizadas con base en los elementos del modelado de red de atención a la salud. La organización de las prácticas en el nivel secundario se encuentra en proceso de consolidación y ha contribuido al desarrollo de mejores prácticas en salud en el local estudiado. Conclusión: La ampliación del acceso a consultas y procedimientos especializados y la articulación de puntos de la red son aspectos de este nivel considerados imprescindibles para la integralidad del cuidado. Este estudio contribuye para el análisis de las prácticas en salud en la perspectiva del modelado de red, desde las interacciones de la atención secundaria y los otros puntos del sistema de salud, que se presentan en proceso de consolidación en el contexto estudiado.

Descriptores: Práctica de Salud Pública; Sistema Único de Salud; Sistemas de Salud; Prestación de Atención de Salud.

\section{Introduction}

As components of a system, health organizations form a complex network, whose attributes include population and territory, logistical structure, and care and management models. The definition, limits and objectives of a health system are specific to each country, in line with its own values and principles. Such systems define the context of the health services, which may be characterized in different ways in relation to integration in the network ${ }^{(1)}$.

The restructuring of the Unified Health System* (UHS), from the perspective of the care network ${ }^{(2)}$ is a strategy for overcoming the fragmented way that health care and management are operated. In Brazil, the health care model is continuously being adjusted to

* The Unified Health System is the Brazilian State Health Service. Translator's note. 
promote integral care for service users, with inclusion and extension of services. For the model's development, horizontality is sought in relations between articulated health facilities, as much for the recovery of health as for preventive measures or health promotion actions ${ }^{(3)}$.

A health care network ( $\mathrm{HCN}$ ) is comprised of a set of organizations which provide actions and services, of different technological density, with a view to comprehensiveness of care. These organizations interact through technical, logistical and managerial support systems $^{(2,4-5)}$.

The HCN is operationalized through the interaction of three main elements: the defined population and health region, the operational structure, and the logical system of functioning determined by the care model(2,4-5).

In the health network, secondary care is made up of specialized ambulatory and hospital services, with an intermediate technological density between that of primary and tertiary care.(2), historically interpreted as procedures of medium-level complexity. This level includes specialized medical services, diagnostic or therapeutic support services, and emergency services.

The access to the actions and the quality of the care offered to citizens are principles of a health care system which reflect the practices carried out. Good practices consist of a complex of techniques, processes and activities, understood to be the best for accomplishing specific tasks, and consistent with values, objectives, evidence for health promotion and understanding of the environment where the practice develops ${ }^{(6)}$.

In the scope of health programs and services, best practices include - in addition to the application of knowledge in specific situations and contexts their implementation, through the appropriate use of resources, to attain results. The effectiveness of a practice is allied with technological efficacy and efficiency, with the aim of contributing to the development and implementation of solutions adapted to similar health problems in other situations or contexts ${ }^{(7)}$.

Thus, by associating best practice benchmarks with secondary care, one enhances the positive responses to the service users' demands in a structuring space in the $\mathrm{HCN}$.

Based in this presupposition, and considering the health network's constitutive elements(4-5), the present research was guided by the following question: How is it that actions and services in the scope of secondary care contribute to the development of best practices in health care? It is sought, therefore, to understand the organization of the health practices, based on the interactions at the secondary healthcare level. In addition to this, it is sought to analyze how the actions and services at this level of care contribute to the development of best practices in healthcare.

\section{Method}

The approach used was qualitative, guided by Grounded Theory (GT). GT procedures aim to identify and relate concepts based on the data investigated, compared and systematically analyzed, presenting a theoreticalexplanatory model of the phenomenon as a product ${ }^{(8)}$.

The study was undertaken in Emergency Departments (ED), Mobile Emergency Care Services (Ambulance service), Policlinics, Specialized dental centers (CEO) and Centers for Psycho-Social Care (CAPS), which are health practice spaces which integrate secondary care, in the municipality of Florianopolis, Brazil - as well as in the health services regulation sector in the municipal government. It is worth emphasizing that in this municipality, hospital care is managed not by the municipality but by the Santa Catarina State Health Department.

Five managers, four health care professionals and three of the service users participated in the study, together making up the fifth Sample Group of the research project titled The Health Care System: best organizational practices in the context of public health policies, financed by the National Council for Scientific and Technological Development (CNPq) - Process \#558425/2008-9. The sample group inclusion is justified by the need to also consider the role of secondary care in the health care system's approach, from the perspective of the care network. The analysis of the data relating to the first four sample groups ${ }^{(9)}$ led to the formulation of the enquiry which gave rise to this fifth group: How are health practices in secondary care organized, and how do actions and services provided at this level contribute to the improvement of the practices in the health network?

The data was obtained in the first quarter of 2011 by one of the authors, through interviews carried out in individual meetings in places chosen by the interviewees, following a semi-structured script, the responses to which were recorded and transcribed. Analysis followed the stages of: codification of the data, formulation of the categories, and reduction, integration and identification of the central category.

The codes were organized according to the elements which comprise the model of the Health Care Network(4-5), adapted for this study: Population/ Territory, Operational System (Diagnostic Support and 
Pharmaceutical and Logistical Assistance) and Care Model (Assistential and Managerial). The software NVivo 8.0 was used for organizing and analyzing the data.

The research project was approved by the Federal University of Santa Catarina's Research Ethics Committee (Decision 257/08). The research subjects were assured of their anonymity and their right to access the data. Their written consent was requested.

\section{Results}

The data analysis process permitted the elaboration of a theoretical model whose central category was termed
"Secondary care in the health care system: structure and organization of the practices in the care network". Four analytical categories were identified, which support the formulation of the theoretical model: Identifying the structure and organization of the secondary care in the health care network; Listing difficulties in the organization of health practices at the level of secondary care; Characterizing best practices at the level of secondary care for structuring the health care network; and Contribution of secondary care to best practices in health. Figure 1 shows the inter-relation between the analytical categories in a schematic form.

Secondary care in the healthcare system: Structure and organization of the practices in the care network

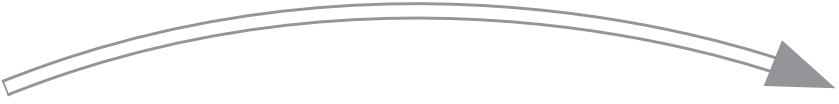

Listing difficulties in the organization of health practices at the level of secondary care
Characterizing best practices at the level of secondary care for structuring the health care network

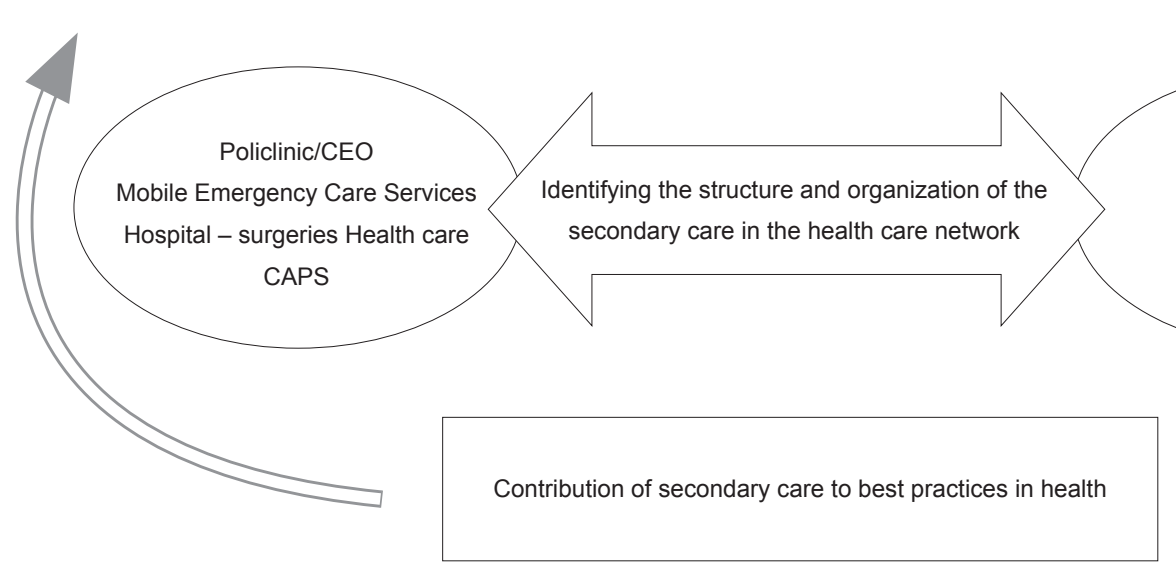

Population/Territory

Support systems

Logistics system

Care Model

Management Model

Figure 1 - Organization of health practices in the care network based on the interactions at the secondary care level: analytical categories

\section{Identifying the structure and organization of the secondary care in the health care network}

This category includes the subcategories: Health facilities; Structure and Organization of Health Practices in Secondary Care.

The health facilities at the secondary level are spaces and structures of the $\mathrm{HCN}$, comprised of the following care units in the municipality of Florianópolis: ED, policlinics, CEO, CAPS and Mobile Emergency
Care Services, and their respective service provision resources, equipment, and human and material resources.

The structure and organization of health practices in secondary care are to do with how the health care practices are established, taking in the policies, principles and norms which govern their functioning. This includes work routines, in terms of the quantity and length of consultations/day, working hours and the specialized care services available. 
The types of care undertaken in secondary care include outpatient consultations in the medical and odontological specialities, emergency care, mental health care, certain types of examination via laboratory tests or imaging equipment, and surgery. The accomplishment of these practices is viabilized by the use of electronic health records, a computerized schedule and the transport of at-risk patients (Mobile Emergency Care Services and ED ambulances).

The service users' access to this level of care is translated by the organization of the demand: ondemand use for emergency care, using risk classification, and demand regulated by the UHS's Ambulatory Care Information System guiding the flow of outpatient attendances referred by the primary care services. The services offered at the secondary level of care may be contracted, affiliated via health insurance and/or provided under agreement with other municipalities.

Considering the benchmark for modeling of health care networks ${ }^{(3-4)}$, the three analytical categories which follow shall be described according to the elements which make them up: Population/Region/Territory, Operational System (Diagnostic Support, Pharmaceutical and Logistical Assistance) and Care Model (Assistential or Managerial).

\section{Listing difficulties in the organization of health practices at the level of secondary care}

In relation to the 'population/territory' element, there is still a lack of clarity as to the type of service provided in the secondary level health facilities, principally concerning the Emergency departments (ED). Not infrequently, the users refer to policlinics when - in reality - they are referring to the service offered by ED, which they use in emergency situations. Thus, the vagueness of the limits of access to ED and the population's lack of understanding of the function and services of secondary care, when located in the same building, are highlighted.

In the operational system, the inexistence and/or lack of maintenance of equipment and the inapplicability of safety norms are raised as obstacles to the provision of better quality service. In the logistical component, the population's access to secondary care has been complicated by: (in the area of transport) the distance between the services, and the inadequate transport to the health facilities: and (in the communications system) communication problems or problems with Ambulatory Care Information Systems. On many occasions the result has been a significant rate of failure to attend hospital appointments.
The difficulties identified in the 'model of care' element in the assistential component have to do with the management of the interactions and articulations between primary and secondary care. Primary care's lack of effectiveness, the existence of unmet demands, the restriction of access, the referral services' lack of responsiveness, the vagueness of referral and counterreferral flows and the non-implementation of care pathways are presented as limiting the service network, compromising its functioning. In the management component on the other hand, the following were indicated as factors which impede the organization of health practices: the lack of qualification and training among the professionals who work in this level of care; the incipient process of planning of services and work routines; the shortage of financial resources for secondary care, and the inadequacy of some services infrastructure.

\section{Characterizing best practices at the level of secondary care for structuring the health care network}

This category describes the practices listed as best by the interviewees, already implemented or in the process of implementation.

The good practices in the population/territory element were interpreted as the provision of good quality care: consultations with scheduled times; attentive professionals; and the guarantee of a return appointment in some of the health facilities.

In the operational system element, in the logistic component, the use of the information system (electronic health records and Ambulatory Care Information System) is considered a good practice, as it makes it possible to register procedures and information electronically and to produce continuity of care. The transport of at-risk patients by Mobile Emergency Care Services was also cited as a good practice.

In the care model element (assistential component) the interviewees indicate as good practice the consultations and attendances carried out in secondary care or in support of primary care. They also point to the fact that effective primary care brings positive consequences for the network as a whole as it reduces the demand on the other levels of care. Organized referral and counter-referral systems, and the definition of points of contact between primary and secondary care, benefit integration and the exchange of experiences between professionals. This interaction facilitates the planning of access and patient attendance flow, in partnership with primary care. 
Services which are well structured and organized - such as, for example, ED - reduce the demand on hospital emergency departments and facilitate referral to tertiary care. Also characterized as good practice was the initiative of use of a common risk classification method by the health facilities, which were under municipal and state management.

The most-emphasized element in the description of good management practice was the process of joint planning of actions and services with the directorates in the central level of the municipal secretariat, both in the definition of timeframes and in the evaluation of actions, in the pursuit of continuous improvement. Remaining on the subject of the management component, the interviewees noted the offering of services with a higher level of technological density, the establishment of norms for the functioning of ED and the implementation of ministerial directives by the municipal Mobile Emergency Care Services as directing towards better practices.

\section{Contribution of secondary care to best practices in health}

This category presents the interviewees' views on continuous improvement in secondary care, in the context of modeling of health care networks. In this regard, guiding and educating the population about the network's functioning (specifying the functions of the services provided at each level of care) are contributions described for the population/territory element. The offering at the secondary level of services in sufficient quantity and quality also contributes to the promotion of integrality in the care network.

The contributions of the logistical component of the operational system element, stressed by the interviewees, include the establishment of well-defined access flow and investments for training the health professionals and the implantation of a bed management center.

In the care model (assistential component), this level's contributions to best practices in the network, listed, were: internal articulation (between the different health facilities in this same (evel); external articulation (between secondary care and the other levels of care); and the extension of access to consultations and specialized procedures. In the management component, the enhancement of the process of planning and of continuous evaluation was emphasized, with the definition of objectives and goals and the establishment of protocols. Also mentioned were the possible contributions arising from: the increase in the care network's component structures; continuing education in health; and from the debate on the role of secondary care in the network. Figure 2 summarizes the difficulties, the practices considered best, and the best practices, comparative to the component elements of the modeling for the HCN.

\begin{tabular}{|c|c|c|c|}
\hline $\begin{array}{c}\text { Components for } \\
\text { modeling of the } \mathrm{HCN}\end{array}$ & Difficulties & Best practices & Contributions to the $\mathrm{HCN}$ \\
\hline Population/territory & $\begin{array}{l}\text { Vagueness of the limits of access to } \\
\text { the health facilities; } \\
\text { Incomprehension of the role of } \\
\text { secondary care and its services. }\end{array}$ & $\begin{array}{l}\text { Consultations with scheduled times; } \\
\text { professional attention; } \\
\text { Guarantee of return appointment in } \\
\text { some health facilities. }\end{array}$ & $\begin{array}{l}\text { Education of the population concerning } \\
\text { the functioning of the } \mathrm{HCN} \text {; } \\
\text { Promotion of comprehensiveness in } \\
\text { the } \mathrm{HCN} \text {. }\end{array}$ \\
\hline Operational system & $\begin{array}{l}\text { Inexistence or lack of maintenance of } \\
\text { equipment; } \\
\text { Inapplicability of safety norms; } \\
\text { Inadequate transport system; } \\
\text { Problems in the communication } \\
\text { system. }\end{array}$ & $\begin{array}{l}\text { Use of electronic health records; } \\
\text { Use of Ambulatory Care Information } \\
\text { System; } \\
\text { Transport of at-risk patients }\end{array}$ & $\begin{array}{l}\text { Well-delineated access flows; } \\
\text { Investments for continuing education } \\
\text { and implantation of bed management } \\
\text { center. }\end{array}$ \\
\hline $\begin{array}{l}\text { Care Model } \\
\text { Assistential component }\end{array}$ & $\begin{array}{l}\text { Lack of effectiveness in primary care; } \\
\text { unmet demand; } \\
\text { Restriction of access; } \\
\text { Vagueness of referral and counter- } \\
\text { referral flows; } \\
\text { Non-implementation of care pathways. }\end{array}$ & $\begin{array}{l}\text { Effective primary care; } \\
\text { Organized referral and counter-referral } \\
\text { systems; } \\
\text { Definition of points of contact between } \\
\text { primary and secondary care; } \\
\text { Common method of risk classification. }\end{array}$ & $\begin{array}{l}\text { Internal articulation; } \\
\text { External articulation; } \\
\text { Extension of access to specialized } \\
\text { consultations and procedures. }\end{array}$ \\
\hline $\begin{array}{l}\text { Care Model } \\
\text { Management Component }\end{array}$ & $\begin{array}{l}\text { Lack of qualification and training } \\
\text { among the health professionals; } \\
\text { Incipient planning process for services } \\
\text { and work routines; } \\
\text { Shortage of financial resources; } \\
\text { Inadequacy of infrastructure. }\end{array}$ & $\begin{array}{l}\text { Joint-planning process of actions and } \\
\text { services with the directorates in the } \\
\text { Municipal Secretariat; } \\
\text { Offering of services with a higher level } \\
\text { of technological density; } \\
\text { Establishment of norms; } \\
\text { Implementation of directives. }\end{array}$ & $\begin{array}{l}\text { Enhancement of the planning process } \\
\text { and of continuous evaluation }\end{array}$ \\
\hline
\end{tabular}

Figure 2 - Difficulties, best practices and contributions of secondary care, according to component elements of the modeling for the $\mathrm{HCN}$ 


\section{Discussion}

Access to secondary care services was indicated as one of the obstacles to the implementation of comprehensiveness in the UHS. This level of care is characterized as the "bottleneck" in the implementation of the $\mathrm{HCN}^{(10-11)}$. The mapping of the health services network by health managers and professionals, constitutes the first step to establishing benchmarks for the attended population, followed by the definition of criteria for flow and counter-flow of attendance. In the HCN modeling, these elements correspond to the population/territory and operational system components(3-5) which represent the definition of the limits of access and flows to the health facilities.

Especially at the level of secondary care, the mapping and characterization of the health services network are useful to municipal and regional managers in organizing the $\mathrm{HCN}$ better ${ }^{(10,12)}$. The principle of comprehensiveness, although partially addressed by the interviewees, deserves particular attention, when one considers that articulated actions, as much in the scope of health policy as in the organization of services and in reorganizing the work process, at all levels of the health system, are intrinsically linked to the operational capability of secondary care in the $\mathrm{HCN}^{(11)}$

The lack of integration between different health facilities, the inadequacy of formal flows to tertiary care, and the disarticulation of the policies which govern secondary care are obstacles to the guarantee of integral care, making this process incomplete in the network ${ }^{(13)}$. In the present research, the interviewees reported the importance of establishing common mechanisms for referral and counter-referral, as an assistential component of the care model(4-5) following the same pattern of risk classification in the municipal and state management institutions. The classification of risk in emergency services aims to prioritize the patients on the basis of the greatest risk, harm to health, or level of suffering, according to clinical severity, instead of meeting the demand in order of arrival(10,14).

The principle strategies for the integration of care levels include the creation and strengthening of regulatory structures within the Municipal Health Departments, with decentralization of functions to the local level, organization of flows, implantation of I.T systems with electronic medical records, and the extension of

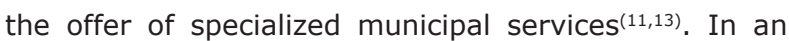

integrated health system, the provision of specialized services must take place in the most appropriate place, preferentially in out-of-hospital settings ${ }^{(1)}$.

One of the principal instruments for integrating primary and secondary care, in Florianópolis, was the implantation of computerized centers for regulation and scheduling of procedures in the health centers (Ambulatory Care Information System) ${ }^{(13)}$, corroborated by the interviewees in this research. Another strategy which broadened access to specialized care and integration of the municipal network was the creation of services on a territorial basis. In Florianópolis, the creation of structures for regulating specialized care is recent, and was driven by the expansion of the Family Health Strategy's coverage and by the adherence to the Pact for Health*, which defined responsibilities in secondary care ${ }^{(13)}$.

The increase of effectiveness in primary care depends on access to consultations and procedures available in secondary care. A good relationship between primary and secondary care is one of the determining factors for this effectiveness ${ }^{(11)}$, which was identified in the present study. Investments in secondary care enhance the effectiveness of primary care. Low effectiveness in primary care, on the other hand, increases the demands on secondary care ${ }^{(13)}$, which was also reported by the interviewees in the present research. At the same time, they reported the need for secondary care to duly attend emergency situations, so that primary care may return to its scheduled duties.

A verticalized hierarchization of the health system hampers the flows of use of the services. The organization of the system in a network, with horizontal relationships, based on the logic of the users' needs ${ }^{(12)}$, constitutes a good practice for bringing in the secondary care services as a health facility in the system(4-5). It should be taken into account that an important part of the resources necessary to guarantee comprehensiveness in health care are concentrated in secondary care. However, in the interviewees' contexts, the poor financing, the restricted incorporation of technology, the lack of maintenance of the existing equipment and the professionals who are undertrained to work in this level of healthcare are all elements which require tackling by UHS managers. The overcoming of these challenges, which are not restricted only to the economic area, qualifies secondary care's insertion in the network and contributes to better practices in health.

* The Pact for Health is a set of institutional reforms dating from 2006. Translator's note 
In this way, the definition of good practices which has been adopted - such as the set of techniques, processes and activities understood as the best for accomplishing a specified task ${ }^{(6-7)}$ permits one to relate the practices described by the interviewees, considering each of these elements. Thus, this study's context shows that the set of techniques at the level of secondary care involves the use of electronic health records, a functioning regulatory system, and a risk classification system common to the different health services which make up the network. The offer of consultations at scheduled times and with a higher level of technological density constitutes good practice in the scope of care activities, as the establishing of norms and the implementation of organizational directives do in management activities. Finally, the flows of referral and counter-referral, guarantee of a return appointment, efficient transport of patients, planning of actions and services and the effectiveness in primary care are included in relation to the processes.

\section{Final considerations}

This study contributes to the understanding of health practices at the level of secondary care, proposing to analyze them from the perspective of network modeling spread by the Pan American Health Organization. As well as contributing to the operational functionality of the health network policy, it advances knowledge production in this specific area of care, which remains under-represented in the literature.

Secondary care performs a vital role in the effectiveness and comprehensiveness of care, by extending access to consultations and specialized procedures, articulating the areas of the HCN which traditionally were distant.

The identification of difficulties in the elements which make up the modeling of the $\mathrm{HCN}$ allowed the identification of current problems at the level of secondary care in relation to population/territory, operational system and care model, which constitute challenges to be overcome. Planning tools must be improved, protocols must be established and service capacity must be improved, in terms of access and variability of the services offered.

Along the same lines, it was possible to present a series of practices which consolidate the continuous improvement of the healthcare system, focused on this level of care. The establishment of flows and counterflows organizes the progress of the user through the network, allowing access and guarantee of continuous care. The emergency services, when well articulated in the network, strengthen the action of primary care. The I.T systems permit better integration of the services.

The organization of health practices, based on interactions at the level of secondary care, is shown to be in a process of consolidation, and is contributing to the development of better practices in health in the area studied.

\section{References}

1. Organización Panamericana de la Salud. Redes Integradas de Servicios de Salud: Conceptos, Opciones de Política y Hoja de Ruta para su Implementación en las Américas. Washington (DC): Organización Panamericana de la Salud; 2010. (OPS. Serie La Renovación de la Atención Primaria de Salud en las América, 04).

2. Portaria GM/MS no 4.279, de 30 de dezembro de 2010 (BR). Estabelece diretrizes para a organização da Rede de Atenção à Saúde no âmbito do SUS. Brasília: Ministério da Saúde; 2010.

3. Silva SF. Organização de redes regionalizadas e integradas de atenção à saúde: desafios do Sistema Único de Saúde (Brasil). Ciênc Saúde Coletiva. 2011;16(6):2753-62.

4. Mendes EV. As redes de atenção à saúde. Ciênc Saúde Coletiva. 2010;15(5): 2297-305.

5. Organização Pan-Americana da Saúde. A atenção à saúde coordenada pela APS: construindo as redes de atenção no SUS: contribuições para o debate. Brasília: Organização Pan-Americana da Saúde; 2011. (OPS. Serie NAVEGADORSUS, 2 ).

6. Kahan B, Goodstadt M. Health Promotion: Developing and implementing a best practices approach to health promotion. Health Prom Practice. 2001;2(1):43-67.

7. Organização Mundial da Saúde. Guia para a Documentação e Partilha das "Melhores Práticas" em Programas de Saúde. Rwanda: Escritório Regional Africano Brazzaville/ OMS; 2008.

8. Baggio MA, Erdmann, AL. Teoria fundamentada nos dados ou Grounded Theory e o uso na investigação em Enfermagem no Brasil. Referência. 2011;3:177-85.

9. Erdmann AL, Mello ALSF, Andrade SR, Drago LC. Organization of care practices in the health network. Online Braz J Nurs. [periódico na Internet]. 2011 [acesso 06 jun 2012];10(1). Disponível em: http://www.objnursing.uff.br/index.php/nursing/ article/view/j.1676-4285.2011.3220.1

10. Oliveira RC, Correa AA, Ferreira AG, Marques ZFA. $A$ reorganização da atenção secundária como estratégia 
para a garantia da integralidade. In: Magalhães HM Jr, organizador. Desafios e inovações na gestão do SUS em Belo Horizonte: a experiência de 2003 a 2008. Belo Horizonte: Mazza Edições; 2010. p. 149-71.

11. Spedo SM, Pinto NRS, Tanaka OY. O difícil acesso a serviços de média complexidade do SUS: o caso da cidade de São Paulo, Brasil. Physis. 2010;20(3):953-72. 12. Roese A, Gerhardt TE. Fluxos e utilização de serviços de saúde: mobilidade dos usuários de média complexidade. Rev Gaúcha Enferm. 2008;29(2):221-9.

13. Almeida PF, Giovanella L, Mendonça MHM, Escorel S. Desafios à coordenação dos cuidados em saúde: estratégias de integração entre níveis assistenciais em grandes centros urbanos. Cad Saúde Pública. 2010;26(2):286-98.

14. Souza CC, Toledo AD, Tadeu LFR, Chianca TCM. Risk classification in an emergency room: agreement level between a Brazilian institutional and the Manchester Protocol. Rev. Latino-Am. Enfermagem. [periódico na Internet]. 2011 [acesso 6 jun 2012];19(1):26-33. Disponível em: http://www.scielo.br/pdf/rlae/v19n1/ pt_05.pdf 